\section{'Ecosystem Service Commodities' - \\ A New Imperial Ecology? \\ IMPLICATIONS FOR ANIMIST IMMANENT \\ Ecologies, with Deleuze and Guattari}

Sian Sullivan
Who gives a chicken's fart about the Garden of Eden and rural tranquillity and improbable things like that? No one thinks about that stuff any more. No one believes in it. All we care about is the next pay packet, the next meal, the next gratification, the next party, the next football match, the next sensation. ${ }^{1}$

\section{TRANSFORMATION}

In 1944, as the Nazi Reich was drawing its final breaths, the economic historian Karl Polanyi wrote in The Great Transformation that ' $[\mathrm{w}]$ hat we call land is an element of nature inextricably interwoven with man's [sic] institutions. To isolate it and form a market for it was perhaps the weirdest of all the undertakings of our ancestors. ${ }^{2}$ He continued by noting that:

... in the field of modern colonization ... the true significance of such a venture becomes manifest. Whether the colonist needs land as a site for the sake of the wealth buried in it, or whether he merely wishes to constrain the native to produce a surplus of food and raw materials, is often irrelevant; nor does it make much difference whether the native works under the direct supervision of the colonist or only under some form of indirect compulsion, for in every and any case the social and cultural system of native life must first be shattered. ${ }^{3}$

In the same year, the free market economist Friedrich von Hayek published The Road to Serfdom. ${ }^{4}$ This seminal work fixes the intellectual argument for a global self-regulating market economy, claiming that this is the only form of political economy that will avoid the serfdom and totalitarianism Hayek saw as flowing inevitably from any planned collectivist or centrally regulated productive system. The road instead was to be open for a capitalist trade of commodities, goods and services extending into all domains of the earth and directed by market prices, enfolded in a monetary system controlled by haute finance - an international banking coalition whose financial freedom was ensured through the release of money's value from the material constraint of the gold standard. ${ }^{5}$
1. Ben Okri, In Arcadia, London, Phoenix, 2002, pp7-8.

2. Karl Polanyi, The Great Transformation: the Political and Economic Origins of Our Time, Boston, Beacon Press, 2001 (1944), p187, emphasis added.

3. Ibid., pp187-88, emphasis added.

4. Friedrich von Hayek, The Road to Serfdom, Chicago, University of Chicago Press, 2007 (1944).

5. A process initiated by the US Federal Reserve in 1933. See Polanyi, op. cit., ch. 1. 
6. Joseph Stiglitz, Globalization and its Discontents, London, W.W. Norton \& Company, 2002; John Perkins, Confessions of an Economic Hitman, San Francisco, Berrett-Koehler, 2004; Naomi Klein, The Shock Doctrine: The Rise of Disaster Capitalism, London, Penguin, 2008.

7. Polanyi, op. cit., especially ch. 6 .

8. Guy Debord, Society of the Spectacle, London, Rebel Press/Dark Star, 1977 (1967); Dan Brockington, Celebrity and the Environment: Fame, Wealth and Power in Conservation, London, Zed Books, 2009; Jim Igoe, Katja Neves and Dan Brockington, 'A spectacular eco-tour around the historic bloc: theorizing the convergence of biodiversity conservation and capitalist expansion', Antipode 42(3), (2010): 496-512; Sian Sullivan, 'Conservation is sexy! What makes this so, and what does this make? An engagement with Celebrity and the Environment', Conservation and Society, forthcoming.

9. cf. Peder Anker, Imperial Ecology: Environmental Order in the British Empire, 1895-1945, Cambridge, MA, Harvard University Press, 2001.

10. Gilles Deleuze and Félix Guattari, A Thousand Plateaus: Capitalism and Schizophrenia,
Hayek's 'manifesto', its elaboration by neoclassical economist luminaries such as the Chicago School of Economists and their most well-known protagonist, Milton Friedman, and its extension globally through a realpolitik of 'economic hitmen', CIA 'jackals', and military adventure, guide global capitalism today, structuring both social and socio-environment relations. ${ }^{6}$ This global machine has required the iterative 'disembedding' of people from land, and of land from 'nature', in service to the exchange of 'fictitious commodities', namely land, money and labour. ${ }^{7}$ These become subsumed under the market mechanism through their radical ideational transformation into the commodity form, and not because they come into existence through their initial material creation as such. The widening disjunctions between human and non-human worlds that this produces are fuelled further by increased capture of nature's sensual reality into the prolific and endlessly exchangeable spectacle of 'celluloid nature', paradoxically making nature's screened and replicated presence both more vividly consumable, at the same time as being somehow less experientially reachable. ${ }^{8}$

How are we to understand the structuring and alienating effects of these contexts as they proliferate in management of 'the global environment' and in the production of new 'imperial ecologies'? ${ }^{9}$ How might the assumed epistemologies and ontologies of human/non-human relationships from which they flow be opened up and discussed freely? What theoretical resources are to hand to assist with a problematisation of current unfoldings of these dynamics in the globally urgent arena of ecological crisis?

In this essay I extend a response to these questions by drawing into the frame some of the theoretical reflections and concepts of post-structuralist philosophers Gilles Deleuze and Félix Guattari. I rely mostly on the 'plateau' 1730 entitled 'Becoming-Intense, Becoming-Animal, Becoming-Imperceptible ...' in their co-produced $A$ Thousand Plateaus; as well as on Guattari's later essay The Three Ecologies. ${ }^{10}$ Sometimes it can appear that a celebration of 'Deleuzian thought' that opens up and radicalises modern biosubjectivities, also can leave us in a place where this radicalisation is a liberation only of our-selves, in relation to the big constructing and constraining 'Daddy' of capitalist and patriarchal authority. But Deleuze and Guattari's work also is much to do with 'the schizoid and social(ised) self' as always opening out to, and both mutually constituting and being constituted by, non-human worlds. As such it becomes a phenomenological movement towards thinking 'the self' as earthed and embedded with, not in, its 'environments': 'environment' here being the 'plane of Nature' that is 'a plane of proliferation, peopling and contagion' - and of process, movement and participatory compositions - beyond the dualism of natural and artificial. ${ }^{11}$

To explore this and bring these gestures into the entwined domains of 'culture' and 'ecology', I want to ask how some of this provocative writing might inform understandings of both the opportunities for capitalism created by contemporary ecological crisis, and the possibilities for a critical political reframing and response. The remainder of this article is structured 
around the juxtaposition of two very different expressions of culture/nature relationships. The first is a current 'imperial ecology' constituted by the ideational transformation of 'the environment' into new commodity fictions called 'ecosystem services'. These are becoming new units of environmental health and degradation that can be paid for, offset and exchanged at various scales, and in which proliferating innovations and investments are occurring in their 'packaging' and trade in new markets. I suggest that this transformation intensifies a classical and modern desire for the release of culture from nature, even as its market rhetoric speaks of a greater valuing of 'nature'. The second is the possibility and implications of an animist 'immanent ecology' in which the human/non-human nexus is more explicitly experienced as one of intersubjective intensities and shared sentience. ${ }^{12}$ Here I work primarily with ethnographic material from Damara or $\neq N \bar{n}$ Khoen people indigenous to north-west Namibia. My intention is to bring some of Deleuze and Guattari's profound suggestions to bear in understanding the constitutive conditions in which these different expressions arise, and the social and environmental trajectories they may bring forth and sustain.

\section{EXPRESSIONS}

From the standpoint of consistency, matters of expression must be considered not only in relation to their aptitude to form motifs and counterpoints but also in relation to the inhibitors and releasers that act on them, and the mechanisms of innateness or learning, heredity or acquisition, that modulate them. ${ }^{13}$

\section{EXPRESSION 1.}

\section{AN IMPERIAL ECOLOGY OF ECOSYSTEM SERVICE COMMODITIES}

Liberated by free-market policies and ideals, capitalism has assumed increasingly nomadic forms that become more-or-less 'released' from the organising striations of State Science and administration. ${ }^{14}$ This appears true in a new globalising series of market exchange and capital accumulation; constituted by the creation and proliferation of new environmental products and currencies, deriving financial value from a growing scarcity of environmental health caused by perceived and actual environmental crisis. $^{15}$

\section{Creating Carbon Earth}

The tremendous proliferation of market exchanges in tradable carbon credits in recent years is the most familiar 'species' in this series, creating, in only a handful of years, a multibillion dollar trade based mainly in Europe but rapidly extending globally. Bankers, investors and speculators now are developing
Brian Massumi (trans), London, The Athlone Press 1987 (1980); Félix Guattari's The Three Ecologies, Ian Pindar and Paul Sutton (trans), London, Continuum, 2000 (1989).

\section{Deleuze and} Guattari, A Thousand Plateaus, op. cit., pp258, 266-7.

12. cf. Noel Keough, 'Sustaining authentic human experience in community', new

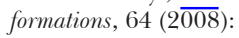
65-77.

13. Deleuze and Guattari, A Thousand Plateaus, op. cit., p331.

14. Ibid., '1227:

Treatise on nomadology - the war machine', pp351-423.

15. Discussed further in Sian Sullivan, 'Green capitalism, and the cultural poverty of constructing nature as service provider', Radical Anthropology, 3 (2009): 18-27, online. 
16. For recent analyses see Steffen Böhm and Siddhartha Dabhi, Upsetting the Offset: The Political Economy of Carbon Markets, online, Mayfly Books, 2009; Tamra Gilbertson and Oscar Reyes, Carbon Trading: How it Works and Why it Fails, Critical Currents 7, Uppsala, Dag Hammarskjöld Foundation, 2009.

17. See www. un-redd.org; Leo Peskett, David Huberman, Ewan Bowen-Jones, Guy Edwards, and Jessica Brown, Making REDD Work for the Poor, London, Poverty Environment Partnership, 2008.

18. Esteve Corbera, Katrina Brown and W. Neil Adger, 'The equity and legitimacy of markets for ecosystem services', Development and Change, 38(4) (2007): 587-613.

19. Details on the Yasuní case come from: Carlos Larrea Yasuni-ITT Initiative: A Big Idea From a Small Country, Ecuador, Ministerio del Ambiente and Ministerio de Relaciones Exteriores, Comercio e Integración, online. http://www. yasuni-itt.gov. ec/download/Yasuni ITT Initiative 1009 pdf, 2009 [accessed 29 November 2009]; and Robin Kraft, 'Pondering Ecuador's Yasuni proposal', online. http://www. speciesbanking. com/pages/ dynamic/article. and exchanging a whole new range of futures and options markets in carbon products. Carbon credits thus are being packaged into increasingly derived financial products, not dissimilar in form and underlying logic to those that triggered the recent financial disaster. This proliferating trade brings forth the world as a carbon commodity space of apparently infinite 'molecular' substitutability. The world is becoming essentialised as a carbon matrix, such that all production and activity is reduced to the concentration and exchange of the element of carbon. ${ }^{16}$ Here I review some recent developments in this rapidly entrenching, if unintuitive, logic of 'carbon earth', because this is underscoring the logic of new and globalising trade in 'ecosystem service commodities', as described below.

A currently 'hot' suggestion in the creation of an earth of carbon capital is the REDD mechanism (Reducing Emissions from Deforestation and Degradation), proposed by the United Nations Environment Programme (UNEP) and partners. ${ }^{17}$ REDD builds on the logic underscoring new international markets for the carbon sequestration services provided by community forests and tree planting in countries such as Mexico. ${ }^{18}$ It proposes equivalence between carbon emitted in the fossil-fuel fumes of cars and industry etc., with that stored in living and decomposing biomass in the myriad forest configurations of long-evolved and diverse assemblages of species. This extends a conceptual context that emphasises carbon commodity exchange within an overall carbon 'budget' for the earth. Under REDD the possibility is that industrial emissions in one location can be 'offset' against the purchase of newly commoditised carbon stored materially in standing forests elsewhere, principally in tropical 'developing countries'. Global carbon-logic thus constructs tropical forests primarily as global 'sinks' to offset and absorb the dumping of industrial carbon emissions, with emitters purchasing carbon equivalence in the newly commoditised dumping spaces of forests in other locations.

An intriguing extension of this logic is the recent offer by Ecuador's President Rafael Correa to forego drilling for oil so as to preserve the rainforest of the Amazonian Yasuní National Park, thus also avoiding production of the emissions that would result from exploitation of Ecuadorean Yasuní oil. This would be in exchange for compensation by the international community for at least half the forgone oil revenue, an amount estimated recently as US $\$ 5.2$ billion. ${ }^{19}$ It is proposed that the initiative be financed primarily through the sale of 'Yasuní Guarantee Certificates' acting as carbon bonds that represent 'avoided emissions', and that these should be brought in as credits within existing carbon markets, particularly the European Union's Emissions Trading Scheme (EU ETS). The Yasuní monies would be placed in an 'international cooperation fund' - a capital fund managed by an international trust; with interest earned invested in Ecuador's transition to a low carbon national economy based on renewable energy, energy efficiency, environmental conservation, and social development. The scheme would work on the basis of the market value (according to the emerging global carbon 
market) attached to preventing release into the atmosphere of the 407 million tons of $\mathrm{CO}_{2}$ that would be emitted from burning the lake of oil occurring underneath Yasuní. Obstacles include volatility in the price of oil. Current low prices are reducing the value of Yasuní oil and acting as a disincentive to drill, thus reducing the relative carbon value of the standing forest. On the other hand, future high oil prices may out compete the value of avoided carbon emissions, making exploitation of the oil the only sensible economic strategy. A further constraint is the lack of clarity regarding whether or not non-development of Yasuní oil indeed will constitute avoided emissions given other sources of oil that can be consumed globally.

The Yasuní proposal marks a significant gesture in which a resourcerich tropical developing country in a sense may hold the international community to account in terms of the latter's apparent new allegiance to tropical biodiversity conservation and reducing $\mathrm{CO}_{2}$ emissions. Thus, if the emerging carbon market really is about valuing reduced and avoided carbon emissions, then this should be reflected in decisions to not develop further sources of emissions, whilst also maintaining significant biodiverse carbon sinks. At the same time, however, if it is only market logic that prevails then there is nothing intrinsic to this logic that would suggest the forest will be preserved and the oil remain in the ground in perpetuity: these questions would depend on fluctuations in market prices (of both oil and carbon), which themselves are dependent on multiple and unpredictable factors and thus are inherently capricious. Warning bells ring, too, in noting the proposed administration of the funds internationally rather than nationally, and the constraints on choices over investment and other assistance that this may signal. And finally, these logics and negotiations remain starkly distant from the embodied worlds - the 'immanent ecologies' - of indigenous Huaorani forest communities - including Tagaeri, Taromenane, Oñamenane and Huiñatare - who live in voluntary isolation in Yasuní, and whose sustaining lifeworlds nevertheless hang in the balance of these distant negotiations.

A critical component of the logic underlying these global market approaches to environmental governance is an understanding that environments, emissions and effects in very different locations, as well as very different 'things', somehow are equivalent and therefore interchangeable and substitutable. It is this unintuitive conflation that conceptually permits carbon production as one thing (for instance industrial emissions) in one location, to be 'offset' against its storage in another thing (such as tropical forests) in another location. A dangerous but indicative extension of this logic is a proposal by the organisation Optimum Population Trust (Opt) that carbon emissions by consumers in the industrialised world might be 'offset' by their paying for reduced fertility (via funded contraception) in the developing world. ${ }^{20}$ Through 'PopOffsets' (www.popoffsets.com), the life of an 'unwanted' African baby, thus becomes 'valued' according to its equivalence to the reductions in estimated carbon emissions represented by its prevented birth, and its ensuing absent-presence as a carbon 'non-person'. page.php?page $\mathrm{id}=6925 \& \mathrm{cod}=1 \mathrm{~s}$ 2009 [accessed 29 November 2009].

20. Optimum Population Trust, Ground-breaking carbon offset project will put population on the Copenhagen agenda, 2009, http://www. optimumpopulation. org/releases/opt. release3dec09. html [accessed 3 December 2009]. 
21. James T. Mandel, C. Josh Donlan and Jonathan Armstrong, 'A derivative approach to endangered species conservation', Frontiers in Ecology and the Environment, (2009), doi:10.1890/070170, p1.

22. Morgan M.

Robertson, 'The neoliberalization of ecosystem services: wetland mitigation banking and problems in environmental governance', Geoforum, 35 (2004): 361-373, p364.

23. See for example F.H. Bormann, 'An inseparable linkage: conservation of natural ecosystems and the conservation of fossil energy', BioScience, 26 (1976): 754-760; and Paul Ehrlich, 'Human carrying capacity, extinctions and nature reserves', BioScience 32 (1982): 331-333.

24. See MEA

Ecosystems and Human Well-

being, Millennium

Ecosystem Assessment, Washington D.C., Island Press, 2005.

25. IUCN, 'Wildlife crisis worse than economic crisis', online. http://www. iucn.org/about/ work/programmes/ species/?3460/ Wildlife-crisis-worsethan-economiccrisis-IUCN, 2009 [accessed 10 August 2009].

26. Maurice Strong, 'A new "rich-poor" war', Lecture to the Korea Institute for International Economic Policy, Seoul, Korea, 22

This model of infinite substitutability, and an accompanying discourse that environmental degradation can be resolved through monetisation and markets, is also being wheeled out for a new range of immaterial environmental products. As Mandel et al note, the desire is 'to use the full power of the market to distribute the burden of conservation'. ${ }^{21}$ A core component of this logic is the drawing of 'ecological relations into circuits of capital', ${ }^{21}$ through creation of markets for new commodities composed of 'ecosystem services'. This involves the following steps.

First, and most importantly, is the instituting of a new ideational construction of nature as provider of 'services' to humans. The term 'ecosystem services' has been used by conservation biologists since the $1970 s .{ }^{23}$ Its endorsement as a hegemonic concept for conceiving both nature and human/environment relationships has received an enormous boost in recent years due to the 2005 publication of the multi-authored, multi-volume United Nations Millennium Ecosystem Assessment (MEA). ${ }^{24}$ This catalogues human-generated change of the biosphere and overwhelmingly uses the language of 'ecosystem services' in speaking of the non-human world. The construction of nature as service-provider to humans begins the discursive and conceptual transformation of earth into a corporation, providing goods and services that can be quantified, priced and traded as commodities. Demand for these is seen as ensuring commodity supply, and commodity decline is seen as manageable through systems of trade in permitted degradation, and/or exchanges with measures of ecosystem health elsewhere. As JeanChristophe Vié, Deputy Head of the Species Programme of the International Union for the Conservation of Nature (IUCN), stated recently: '[i]t's time to recognize that nature is the largest company on Earth working for the benefit of 100 percent of humankind - and it's doing it for free'. ${ }^{25}$ Or as Maurice Strong, Secretary General of both the 1972 UN Conference on the Human Environment in Stockholm and the 1992 Earth Summit in Rio, and the First Executive Director of the UNEP, asserted in 1996: '[i]n addressing the challenge of achieving global sustainability, we must apply the basic principles of business. This means running "Earth Incorporated" with a depreciation, amortization and maintenance account'. ${ }^{26}$ Today this statement is on the website of EKO Asset Management Partners, who describe themselves as 'a specialized investment firm focused on discovering and monetizing unrealized or unrecognized environmental assets ... in short, a "merchant bank" for the world of environmental markets'. ${ }^{27}$ EKO's investors hail from the world of haute finance and include James Wolfensohn, 9th president of the World Bank Group, as well as Lord Jacob Rothschild and Alexander and Ben Goldsmith of the Rothschild and Goldsmiths banking dynasties. In short then, the idea of 'ecosystem service commodities' is making nature increasingly intelligible to a capitalist market system and the language of finance. 'Ecosystem services' has rapidly become a hegemonic term and concept in global environmental 
governance: acclaimed as a 'unifying language'28 even as it effects epistemic exclusions and ontological heresies for many (elaborated below). ${ }^{29}$

The second step in the process is the effort to conceptually break 'nature's services' down into new discrete categories that might lend themselves to quantification and the attaching of financial value. The MEA affirms twentyfour service categories, including: provisioning services (food, water, timber, fibre, etc.), regulating services (floods, droughts, land degradation and disease), supporting services (such as soil formation and nutrient cycling), and non-material cultural services (recreational, spiritual, religious, etc.). ${ }^{30}$ Ecosystem service schemes involve the measurement of defined services via a range of Rapid Assessment Methods developed by relevant scientists, and their translation into numerical scores representing the state of the ecosystem service. ${ }^{31}$ The term 'rapid' again might sound some alarm bells, and, as Kosoy and Corbera assert, significant ecological issues emerge from a reducing of ecosystem complexity and dynamism to a few delineated 'services' ${ }^{32}$

Third, the quantification skills of ecological science, economics and finance are combined to assign prices to these ecological 'services', thereby bringing them forth as new, albeit fictional, commodities. The ensuing attachment of numbers representing financial value to discrete aspects of 'the environment' and ecological processes may appear rigorous and convincing on paper; but much of this arises through rather $a d$ hoc methodologies such as contingent valuation, an economic method that has received intense criticism from within economics. ${ }^{33}$ Nevertheless, the image in figure 1, from a policy brochure by the United Nations Environment Programme (UNEP) and IUCN publicising the possibility of international Payments for Ecosystem Services, clearly conveys the alchemical optimism of attaching financial signs to measures of ecological health: money will, it seems, grow on trees.

Fourth, and with the assistance of financial investment, new markets are

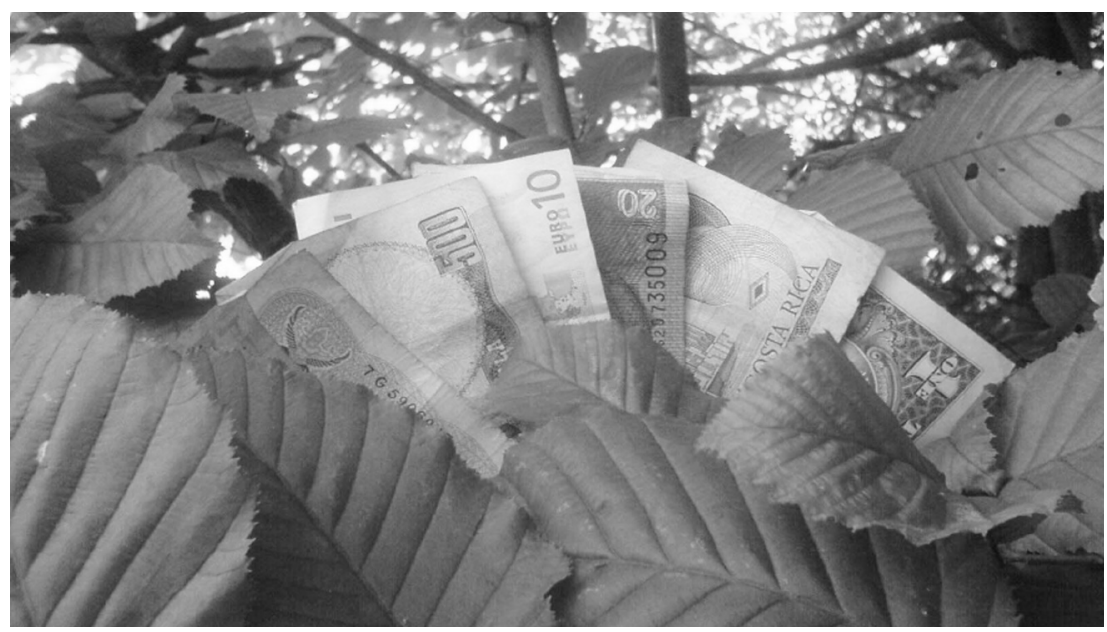

Figure 1: Money grows on trees. Source: UNEP/IUCN Developing International Payments for Ecosystems Services: Towards a Greener World Economy, online. http://www.unep. ch/etb/areas/pdf/IPES_IUCNbrochure.pdf, 2007, p1 [accessed 23 November 2008].
October 1996, online. http://www. mauricestrong. net/2009032079 speeches2/ speeches2/koreaeconomic-policy. html, 1996, [accessed 30 November 2009].

27. http://ekoamp. com/who/

28. UNEP/IUCN

'Developing

international payments for ecosystem services: towards a greener world economy', online. http://www. unep.ch/etb/ areas/pdf/IPES IUCNbrochure.pdf, 2007 [accessed 23 September 2008], p2.

29. Sullivan, op. cit.; J. Stephen Lansing, Philip S. Lansing, and Juliet, S. Erazo, 'The value of a river', Journal of Political Ecology, 5 (1998): 1-21.

30. MEA, op. cit. p3.

31. Robertson, op. cit., p367.

32. Nicolás Kosoy and Esteve Corbera, 'Payments for ecosystem services as commodity fetishism', Ecological Economics, 69(6), (2010): 1228-36, doi:10.1016/. ecolecon.2009.11. 002 .

33. Clive Spash, 'Ecosystems services valuation', Socioeconomics and the Environment in Discussion, CSIRO WorkingPaper Series 2008-03, online. http://csiro. au/files/files/pjpj. pdf, [accessed 21 February 2009]. 
34. Robertson, op. cit., p365.

\section{Tobias}

Kretschmer, De

Beers and Beyond:

The History of the

International Diamond

Cartel, London,

London Business

School, Online.

http://pages.stern.

nyu.edu/ lcabral/

teaching/debeers3

pdf, [accessed 23

December 2009].

36. Mandel et al., op. cit., p1.

37. Jessica Fox and Anamaria Nino-

Murcia, 'Status of species conservation banking in the United States', Conservation Biology, 19(4) (2005): 61007.

38. Robertson, op. cit.

39. online at http:// www.speciesbanking. com/pages/dynamic/ web.page.php?page name $=$ overview\&s ection=about_us section, [accessed 30 November 2009].

40. online at http:// ecosystemmarket place.com/pages/ static/about. php, [accessed 30 November 2009].

41. See FAO, Livestock's Long Shadow, Rome, FAO, online. http://www. fao.org/docrep/ 010/a0701e/ a0701e00.htm, 2006 [accessed 26 September 2008].

42. Corbera, et al., op. cit, pp608, 588.

43. Ibid. created whereby it becomes possible for these new environmental commodities to be traded. As Robertson notes, ${ }^{34}$ the optimistic logic is that commodities that are in demand will increase in supply. Thus if environmental health is scarce and in demand, then its commoditisation and market exchange should lead to increased market supply, and thus to increased environmental health. But surely there is another, rather concerning, logic to capitalist market exchange; which is that commodity value (such as price) increases with the scarcity of that commodity (hence de Beers asserts tight-fisted control over the availability of diamonds on the world market, so as to maintain prices).$^{35}$ Logically then, species and ecosystem services assume higher market value when they are in decline. Indeed, it is precisely because of current environmental crisis that environment health now is deemed valuable enough to invest in its commodification.

The picture is completed by the entrance of these new environmental commodities and markets into the worlds of banking and finance via investment and trade. This permits development of increasingly complex derived products such as options and futures, the accruing of more 'value' via speculative trade in 'currencies' of ecosystem function, and the juggling of product performance and interest rates. Mandel et al, for example, propose the creation of 'modified derivative contracts to sell species' extinction risk to market investors and stakeholders', suggesting that 'a biodiversity derivatives program' could 'align stakeholders' interests and create incentives for private conservation efforts' ${ }^{36}$ The logical extension is the emergence of companies, banks and stock exchanges established purely to service exchange in new environmental commodities, which is exactly what is happening. Withincountry 'conservation banks' and 'species banks', involving the creation and trading of 'credits' representing biodiversity values on private land, are proliferating, particularly in the US, ${ }^{37}$ as are wetland mitigation banks for addressing wetland health and degradation. ${ }^{38}$ Online mechanisms for managing exchanges remotely also are proliferating. The website www. speciesbanking.com, for example, acts as a 'clearinghouse for the species credit trading industry' in the US, allowing 'conservation bank owners to publicize credit availability, credit buyers to find solutions to their mitigation needs, [and] prospective bank developers to research current market conditions', and is looking to expand coverage to include emerging species banks elsewhere. ${ }^{39}$ This banking model is part of the 'Ecosystem Marketplace' network which 'seeks to become the world's leading source of information on markets and payment schemes for ecosystem services' ${ }^{40}$ Environmental asset management and investment companies are proliferating, such as EKO noted above. And carbon now has its very own stock exchanges in London (www. ecx.eu), Chicago (www.chicagoclimatex.com), Montreal (www.mcex.ca), and China (www.chinatcx.com.cn), accompanied by the recent introduction of a range of derivative options and futures contracts based on company emission allowances.

Through the construction of these new commodity markets those able 
to access the new financial value accruing to 'nature's services' can scoop up income from their exchange. In the world of carbon markets, tradable carbon credits have been allocated to heavy emitters (for instance in the EU ETS), thus in fact allowing them to profit from new trade in these credits. In the discourse of development and poverty alleviation, a dominant justification of these market approaches is that they will allow people to access new income from living in maintaining relationships with landscapes now valued globally, thus preventing their conversion into less desirable forms at the same time as permitting economic growth. ${ }^{41}$ Whether or not such redistributions occur in practice remains to be seen: as Corbera et al articulate, 'markets are blunt instruments with respect to issues such as procedural fairness and equitable distribution', and 'those who benefit from the market exchange are not necessarily the direct resource users'. ${ }^{42}$ A compounding factor is the extent to which communities can assert property rights over newly tradable service commodities: capitalist market exchanges require inalienable property rights over any traded commodity, and additional complexities are raised when these services are situated in non-formal common property regimes. ${ }^{43}$

What is inescapable is that the process in its entirety effects something of Polanyi's concept of 'indirect compulsion' to global interests: ${ }^{44}$ enfolding local livelihoods and other cultural lifeworlds into the determinations of desires and values established in distant locations and spread globally via incursions of development aid, conservation finance and capital. Illustrating this further are recent proposals that communities in low income nations finance poverty alleviation and economic development through offering newly monetised 'environmental assets' as collateral for 'environmental mortgages' These would be loans linked to independent measures of the state of an environmental asset and offered by international environmental investors. ${ }^{45}$ Relevant here of course is the question of who then owns the asset/collateral in instances of default. An additional way that these new values might be mobilised is through permitting private landholders, including corporations, to realise and exchange the additional financial value that might be added to appropriated land they now own, via financial audit of the ecosystem services embedded in that land. Thus, the mining conglomerate Rio Tinto, in tandem with the IUCN, are exploring 'opportunities to generate marketable ecosystems services on land owned or managed by the company'. ${ }^{46}$

These processes, and the institutions and structures with which they are linked, seem to be further conceiving and producing the Earth as a smooth, abstract, space for 'nomadic' capture and exchange by the realm of the disembedded and disembodied: namely a transcendental corporate capital and finance. ${ }^{47}$ This imagining is depicted well by figure 2 , showing the corporate logos of around 200 multinational companies distributed evenly across a featureless sphere representing earth. Accompanying this privileged distribution of corporations throughout the world is the conceptual creation of earth as a giant abstract environmental 'ledger'; ${ }^{48}$ structured to permit the exchange and infinite substitutability of new commodity fictions based
44. Polanyi, op. cit., p188.

45. C. Josh Donlan, 'Opportunities for debt investment for environmental conservation', http://www.advanced conservation. org/mortgages/ environmental mortgages2EX. pdf, n.d. [accessed 7 December 2009]; C. Josh Donlan, 'Why environmentalism needs high finance', online at: http:// seedmagazine.com/ content/article/why envronmentalism_ needs_high_ finance/, 22 April 2009 [accessed 7 December 2009].

46. Josh Bishop, 'Building biodiversity business: notes from the cutting edge', Sustain, 30 (2008): 22-23.

47. cf. Michael Hardt and Toni Negri, Empire, Cambridge, Massachusetts, Harvard University Press, after Deleuze and Guattari, op. cit., p387.

48. cf. Igoe et al., op. cit.

49. WBCSD 'About the WBCSD, online at: http://www.wbcsd org/templates/ TemplateWBCSD5/ layout.asp?type $=$ $\mathrm{p} \&$ MenuId $=\mathrm{NjA}$ \&doOpen $=1 \& \mathrm{Cl}$ ickMenu=LeftM enu, [accessed 7 December 2009].

50. IUCN 'About IUCN', online at: http://www.iucn. org/about/, [accessed 7 December 2009]. 


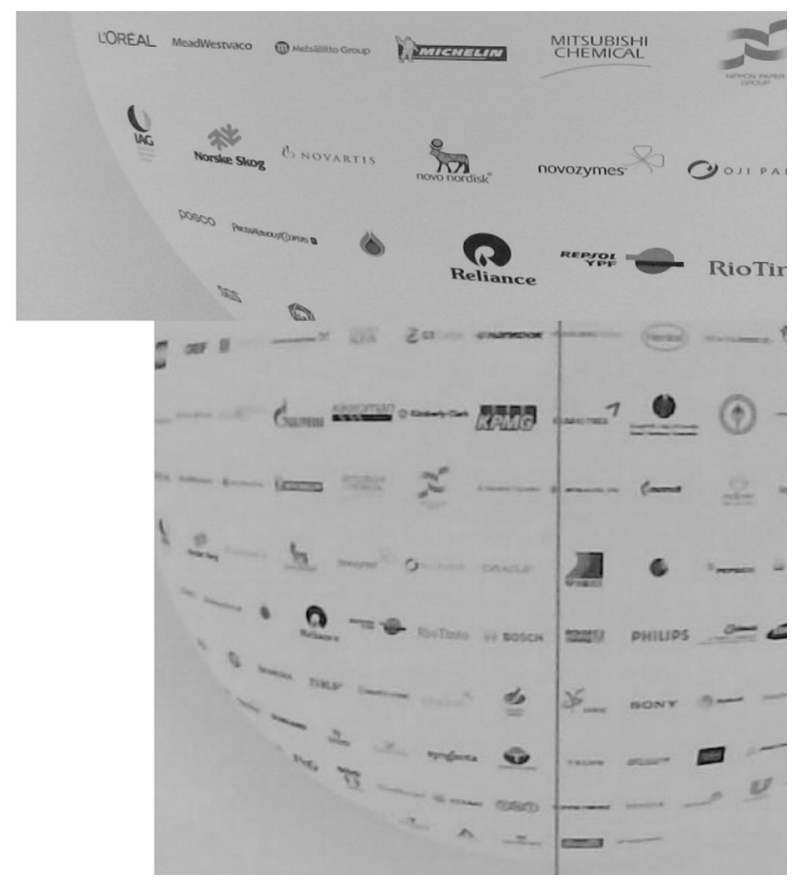

Figure 2: The world according to the World Business Council for Sustainable Development (WBCSD): a smooth earth populated by corporate logos. From the WBCSD display at the 2008 World Conservation Congress of the International Union for the Conservation of Nature (IUCN). Photo: Sian Sullivan.

on newly constructed environmental goods, services and degradations.

\section{Bizarre bedfellows}

This commoditisation of the earth's 'services' to fuel capitalist market expansion in the realm of environmental crisis is being fostered and promoted by the world's largest environmental organisations. The image in Figure 2, for example, is not from a conventional business gathering

51. http://www. naturalcapitalproject. org/home04. html, [accessed 16 December 2009].

52. Conservation International, Nature Provides: Ecosystem Services and their benefits to Humankind, online at: http:// www.conservation. org/Documents/CI EcosystemServices Brochure.pdf, [accessed 7 December 2009] p6.

53. Molly Bergen, Mapping Nature's Benefits, online at: http://www. conservation.org/ FMG/Articles/Pages/ mapping_natures_ benefits ARIES. aspx, 17 November 2009 [accessed 7 December 2009].

54. The Aries Consortium, The ARIES Project: Artificial Intelligence for Ecosystem Services,
- the World Economic Forum perhaps. It is from a prominent exhibition stand at the 2008 World Conservation Congress held by the IUCN, and publicises the reach and concerns of the World Business Council for Sustainable Development (WBCSD). The WBCSD is 'a CEO-led, global association' of some 200 of the world's largest corporations, ${ }^{49}$ and the IUCN 'is the world's oldest and largest global environmental network'. ${ }^{50}$

The global mega-NGOs of Conservation International (CI), The Nature Conservancy (TNC), and the World Wide Fund for Nature (WWF), in collaboration with CEOs on their boards and wealthy, largely US-based, philanthropic foundations, are all endorsing and developing marketapproaches to conservation based on newly created environmental products that can be exchanged remotely. TNC and WWF, with Stanford University, are collaborating on a ten-year 'Natural Capital Project', developing tools for the modelling and mapping of the economic value of ecosystem services and constructing a 'natural capital database'. ${ }^{51}$ And in 2009 CI and partners launched its project 'ARIES', or 'Artificial Intelligence for Ecosystem Services'. This is 'a web-based technology ... offered to users worldwide to assist rapid ecosystem service assessment and valuation at multiple scales, from regional to global'. ${ }^{52}$ It is described as 'poised to revolutionize the way governments, businesses and communities think about and manage their local environments'. ${ }^{53}$ The output of 'an ARIES user session' is 'an environmental asset portfolio that describes in depth the spatial distribution of ecosystems and ecosystem services in the area, their potential and realized economic values'. ${ }^{54}$ Figure 3, from the ARIES Facebook site, captures this sense of transcendent, remote ecosystem management and control. The 
Figure 3: Logo for the ARIES project Artificial Intelligence for Ecosystem Services, run by the ARIES consortium of Conservation International, Earth Economics Institute and The Ecoinformatics Collaboratory, Gund Institute for Ecological Economics, University of Vermont. Source: the ARIES Facebook site, online. http://www.facebook.com/note. php? note_i $\overline{d=92347702878 \text {, [accessed } 7}$ December 2009].

Aries constellation signifying the ARIES project and web application,

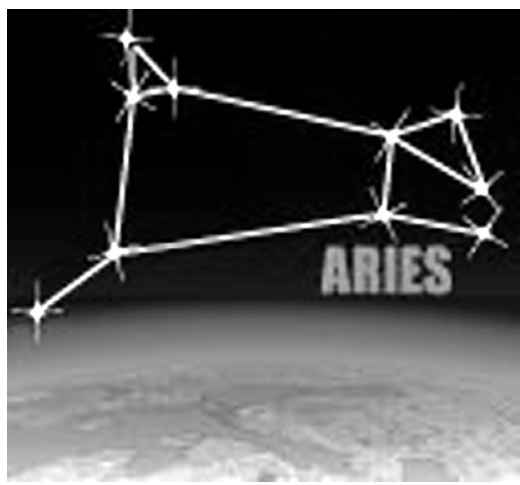
hovers in dark space over the surface of a distant earth: surveying landscapes and capturing environmental information - the choice and form of which is structured in highly contingent ways - so as to empower decision-making processes based on digital maps and models.

Robertson argues that in these collaborations, measurements and new equivalences, 'the institutional logic of capital is dominant (but not determinative) over the institutional logic of science, in its very ability to compel ecologists to create assessment measures that "work" for capital". 55 In ecosystem assessments for the creation of ecosystem service commodities then, ecological scientists work to create ' $[\mathrm{t}]$ he nature that capital can see' ${ }^{56}$ For Guattari, these processes, dynamics and ensuing structures become '... the imperium ... of a global market that destroys specific value systems and puts on the same plane of equivalence: material assets, cultural assets, wildlife areas, etc. ${ }^{57}$ The imperial ecology of market environmentalism thus iterates and consolidates what Guattari refers to as the 'unidimensionalizing' value system of the west, becoming further comprehensible and consumable via the "mass media serialisms" ${ }^{58}$ of the life-shattering spectacle. ${ }^{59}$ As such these phenomena extend and effect 'a blind process of [auto-iterative] proliferation' that is beyond the control of persons or groups,${ }^{60}$ and which can be seen to be one of the further release of 'nature value' from the world of embedded materiality to increasingly virtual realms. To complete the picture, the 'opportunity' of environmental crisis becomes managed via 'remote control', ${ }^{61}$ such as in emerging stock exchanges for speculative trading on environmental products.

It seems hard to avoid a view that the whole nomadic nexus of networks and alliances between mega-environmental NGOs, philanthropic foundations, corporations and the finance-sector is producing and consolidating an imperial 'ethnic-rich', poised to capture the scarcity value of environmental health and the business opportunities surrounding this. ${ }^{62}$ At the same time, and as illustrated in Figure 3, culture - the realm of human experience and decision-making - seems to become more separate and removed from nature than ever. Nature meanwhile, is further abstracted, distanced, flattened and somehow dematerialised; to online at: http://esd. uvm.edu/uploads/ media/ARIES.pdt, 2009 [accessed 7 December 2009], p1 emphasis in original; also see, Ferdinando Villa, Marta Ceroni, Ken Bagstad,

Gary Johnson and Sergey Krivov, ARIES (ARtificial Intelligence for Ecosystem Services ): a new tool for ecosystem services assessment, planning, and valuation', BioEcon., 2009, online at: http://www.ucl.ac.uk/ bioecon/11th 2009/ Villa.pdt, [accessed 7 December 2009].

55. Robertson, op cit., p366.

56. Morgan M. Robertson, 'The nature that capital can see: science, state, and market in the commodification of ecosystem services', Environment and Planning D: Society and Space, 24 (2006): 367-87, p368.

57. Guattari, op. cit., p20.

58. Ibid., p21.

59. Debord, op. cit.

60. Guattari, op. cit., pp91-2.

61. Guattari, op. cit., pp. 28-29, after Paul Virilio, e.g. The Vision Machine, Julie Rose (trans), London and Indiana, BFI and Indiana University Press, 1994.

62. cf. Brockington, op. cit., chapter 5 .

63. Robertson, 'The neoliberalization of ecosystem services', op. cit., p365. 
64. Guattari, op. cit., p29.

65. Guattari, from Chaosmosis, quoted in Guattari, ibid., p82.

66. cf. Deleuze and Guattari, op. cit., p293.

67. Deleuze and Guattari, op. cit., especially November 28, 1947: 'How do you make yourself a body without organs?', pp 149-166.

68. Daniel Miller, Stuff, Cambridge, Polity Press, 2010, p 10 .

69. Chris Low, Khoisan Medicine in History and Practice, Köln, Rüdiger Köppe Verlag, 2008.

70. J. David LewisWilliams and David G. Pearce, San Spirituality: Roots, Expression, and Social Consequences, New York, Altamira Press, 2004.

71. Kadisen | | Khumub, Andrew Botelle, Robert Scott and Charles Bosman, Journey of a Rain Shaman, Windhoek, Mamokobo Research and Productions, 2007.

72. Deleuze and Guattari, op. cit., p238.

73. Ansie Hoff, 'The water snake of the Khoekhoen and |Xam', South African Archaeological Bulletin 52 (1997): 21-37; Sigrid Schmidt, 'Mythical snakes in Namibia', in Andrew be valued and exchanged remotely, via the transformation of its sensual and embodied aspects into the transcendent zeros and ones of more easily manipulable digital information. As such then, these new markets extend and entrench modernity's perceptual reality which is one that assumes distinct separations between culture and nature; that conceives of 'the environment' as passive 'external presence' ${ }^{63}$ or background to transcendent human activity and desire; and that venerates conceptual schema of distinct, quantifiable and exchangeable categories.

\section{EXPRESSION 2.}

\section{AN ANIMIST IMMANENT ECOLOGY OF INTERSUBJECTIVE SENTIENCE}

Guattari writes in The Three Ecologies that [n]ow more than ever, nature cannot be separated from culture'; ${ }^{64}$ and I am with him when he asks:

How do we change mentalities, how do we reinvent social practices that would give back to humanity - if it ever had it - a sense of responsibility, not only for its own survival, but equally for the future of all life on the planet, for animal and vegetative species, likewise for incorporeal species such as music ... [(re)engendering] the feeling of fusion at the heart of the Cosmos. ${ }^{65}$

One way perhaps, is to listen to people - and to experiences - that express other relationships with non-human worlds: if it is possible to do this without falling prey either to kitsch romanticism, essentialism and colonial nostalgia, or to cynical dismissal. ${ }^{66}$ Deleuze and Guattari's writings entice with their fascination of the 'non-ordinary'; that is, of the apparently 'non-Oedipalised' cultural and subjective worlds they see in both non-modern and non-capitalist cultures, and in the escaping subjective intensities of the trans-personal 'Bodywithout-Organs' ${ }^{67}$ This is a project that fits well with an anthropological intent to engage with relationships between global and local phenomena, thereby making relevant 'the consequences of the universal for the particular and of the particular for the universal'. ${ }^{68}$

In this part of the essay, then, I seek to embody this intent by introducing something of what I bring to my understandings of human/non-human relationships, as well as to my reading of Deleuze and Guattari. This is the on and off experience, since the early 1990s, of living and interacting with people indigenous to north-west Namibia who have different, and, to me at times, epistemologically bewildering, conceptions of human/non-human relationships, of time and causation, and of community. I draw here on my own field experiences as an anthropologist in this context with a KhoeSān people named Damara or $\neq \mathrm{Nu}$ Khoen, as well as on two significantly corroborating texts: Chris Low's Khoisan Medicine in History and Practice ${ }^{69}$ and San Spirituality 
by David Lewis-Williams and David Pearce. ${ }^{70}$

This is a context ... Where a rain shaman dances into trance, and in this state of consciousness is able to climb a rope of light into a different but no less real world where he negotiates with the rain goddess |Nanus, imploring her to allow him to retrieve life-giving rain, which he then brings back with real effect. ${ }^{71}$ It is where people can shapeshift into lions, and be witnessed doing so. As Deleuze and Guattari affirm of these semiotic identifications: '[b]ecomings-animal are neither dream nor phantasies. They are perfectly real'. ${ }^{72}$ And where giant snakes, sometimes with antelope horns on their heads and quartz or lights in their foreheads, roam the landscape, filling it with intense potency. ${ }^{73}$ Where the fat of certain animals carries the potency of that animal; and where human sweat can be amongst the most potent healing substance of all. Where illness can be carried and caused by wind, smell and energetic arrows; and where a healer works by manipulating energetic forms called Igais so that they stand up straight in the body. ${ }^{74}$ Where a perfume or sâi of aromatic plants can be used to calm agitations of potency, or to raise potency, depending on requirements and contexts. ${ }^{75}$ And where the most allknowing deity is an insect - the praying mantis - who capriciously shapeshifts into and shares dynamic kin relations with many other animals: ${ }^{76}$ somehow meeting Deleuze and Guattari's suggestion that ' $\mathrm{t}] \mathrm{he}$ insect is closer, better able to make audible the truth that all becomings are molecular ... [and t]he molecular has the capacity to make the elementary communicate with the cosmic ${ }^{77}$ All of these phenomena, spoken of in contemporary times, sit within and affirm an old and broad KhoeSān conceptual world that speaks suggestively through the layers of rock art imagery that is enormously prolific in southern Africa (see figure 4).

In their rhizomic, semiotic, reorganisation of modern Western categories (subject/object, body/mind, nature/culture) into a differently

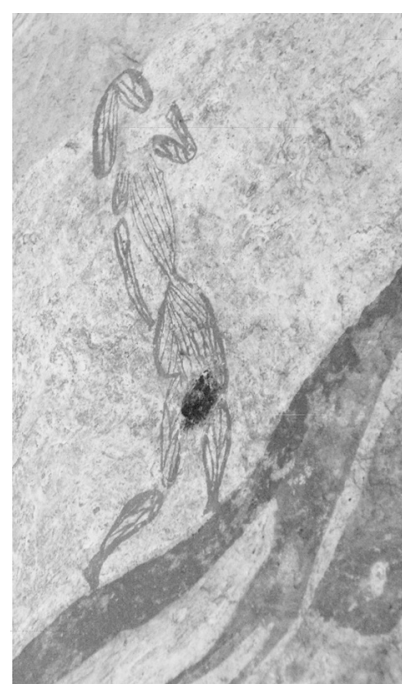

Figure 4: Southern African rock art images, depicting possible key motifs in KhoeSān animist cosmology. Left: a healer climbing a rope of light into the spirit world? Photo: Sian Sullivan, Mason's Shelter, Dâures. Centre: drawing in animals? Photo: Sian Sullivan, Dâures. Right: giant water snake? Chris Low, reprinted with permission.
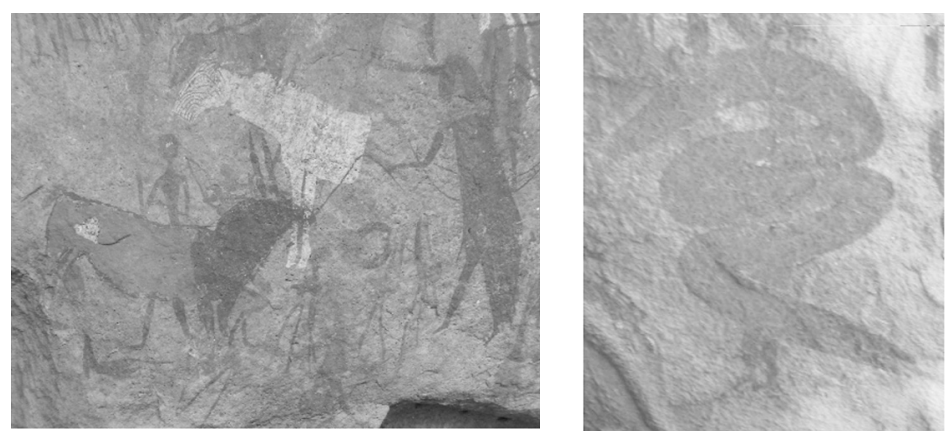

Bank, Hans Heese, Chris Loff (eds), 'The proceedings of the Khoisan Identities and Cultural Heritage Conference, Cape Town 12-16 July 1997', Institute for Historical Research, University of the Western Cape, Bellville, South Africa, and Infosource, Glasgow, 1998, pp269-280;

Chris Low and Sian Sullivan, 'Shades of the rainbow serpent: a KhoeSān animal between myth and landscape in southern Africa', paper presented at Living Landscapes conference,

Aberystwyth

University, 18-21 June 2009.

\section{Low, op. cit.}

75. Sian Sullivan, 'Gender,

ethnographic myths and community-based conservation in a former Namibian 'homeland", pp142164 in D. Hodgson (ed), Rethinking Pastoralism in Africa: Gender, Culture and the Myth of the Patriarchal Pastoralist, Oxford, James Currey, 2000; Christopher H. Low, 'Different histories of buchu: Euro-American 
appropriations of San and Khoekhoe knowledge of buchu plants', Environment and History, 13(3) (2007): 333-61.

76. Personal field notes.

77. Deleuze and Guattari, op. cit., p308, emphasis in the original.

78. Ibid. p273.

79. Ibid. p272

80. Ibid. p309; on improvisation also see Jeremy Gilbert, 'Becoming-music: the rhizomatic movement of improvisation', in Ian Buchanan and Marcel Swiboda (eds) Deleuze and Music, Edinburgh, Edinburgh

University Press, 2004, pp118-38.

81. Guattari, op. cit., p21.

82. Also see Sullivan, 'Green capitalism', op. cit; Sian Sullivan, 'Folk and formal, local and national: Damara cultural knowledge and community-based conservation in southern Kunene, Namibia', Cimbebasia 15 (1999): 1-28.

Figure 5:

Nathan $\neq \hat{\text { Uina }}$

Taurob and

family greet and gift the spirits of the land in Giribes plains, north-west

Namibia. Photo: Sian Sullivan. understood language of complex system flows and intensities, Deleuze and Guattari's entwined and mutually enforcing concepts of 'becoming-animal', 'becoming-molecular' and 'becoming-intense' offer a conceptual entrance into appreciating these 'counter existential', but actually common-place, experiences and configurations. Therianthropes abounding in the rock-art and concepts of the region, healers shapeshift into animals, everyone knows it is possible to dance the kudu and other animals: all affirming the 'reality of becoming-animal, even though one does not in reality become animal'. ${ }^{78}$ The skilled becoming-intense of a healer focuses potency through dance, song, fire, and the use of sâi: consciousness shifting and moving to and through other worlds, populated by beings known and related with through millennia of dynamic biocultural concerns and desires. The 'process of desire' and of strong intent, thus manifests as shifting perceptual intensities: such that '[b]ecomings-animal plunge into becomings-molecular' ${ }^{79}$ A healer's skill permits this 'becoming-molecular' via transversal movements into other perceptual domains; disciplined return to the organised body and ego then makes possible the sharing of journey information so as to guide pragmatic decisions for sustaining social and environmental health.

Importantly, this is where the work and commonplace of human agency is explicitly to flow with, respond to and generate, an endlessly moving and cycling swirl of potent and productive intensities such that inappropriate agitations are calmed, and great energy and commitment can be directed towards raising potency when required. Where, in ideal terms, what is valued is the ability and skill to improvise, play and dance with "what already is musical in nature'.$^{80}$ This skill confers what Guattari refers to as the 'significance of human interventions', ${ }^{81}$ in a context of an always and potently communicative non-human world that also is sentient and asserts agency. So in Figure 5 Nathan $\neq$ Ûina Taurob (on the right), his daughter and her partner sit with the land with which they are connected, talking to and gifting the spirit and ancestral presences embodied there: a respectful act of listening and communicating that preceded the harvest of environmental 'resources' on that day. ${ }^{82}$ Everything

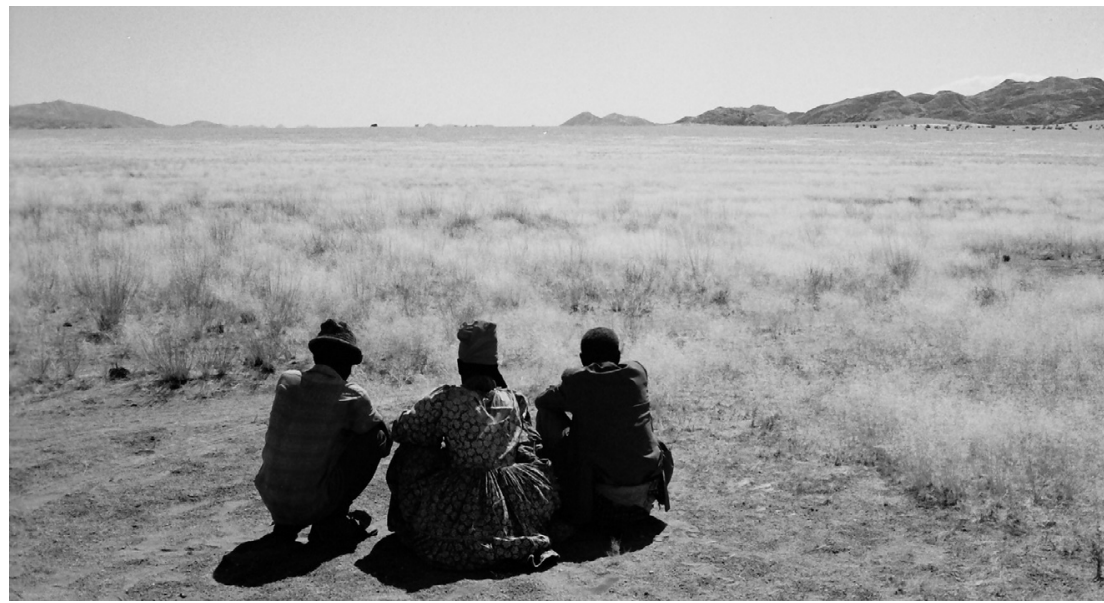


in the picture speaks of closeness, humility and love: of the consciousness and experience of an immanent human/non-human community, activated, enhanced and appreciated through acts of listening, communication and sharing. As Deleuze and Guattari state, ' ... the plane of composition, the plane of Nature, is precisely for participations of this kind' ${ }^{83}$

In combination, these are conceptions and practices of being human in relation to non-human worlds that also have ethical and political effects, one of which has been to exist for millennia in a maintaining relationship with a spectacular landscape that now is globally highly sought after and marketed for its biodiversity, tourism and ecosystem service values. They constitute ways of knowing, associated practices and affirmed ontologies which generate and become "[e]cological praxes ... [that] ... run counter to the "normal" order of things ... invok[ing] other intensities to form ... [different] existential configurations'. ${ }^{84}$ As such, they speak of routes into what Guattari terms 'ecosophy', describing this as 'an ethico-political articulation ...' between the three ecological registers' of 'the environment, social relations and human subjectivity'. This becomes an ecological philosophy that reembeds relationships between interior (subjective) and exterior (social and environmental) potencies. ${ }^{85}$

Deleuze and Guattari state that ' $[\mathrm{t}] \mathrm{his}$ is not animism, any more than it is mechanism; rather it is universal machinism: a plane of consistency occupied by an immense abstract machine comprising an infinite number of assemblages' ${ }^{86}$ I have to be true here to my intuitive resistance to their fetishising of the term machine: is it not the ideational shift to a deadened machine-like earth that has made the extractive and disrespectful excesses of modernity possible? ${ }^{87}$

I want, instead, to use their writing and concepts to reactivate the term and concept of animism in thinking about 'earth's nature'; and in rekindling human/non-human relationships and practices that are themselves in greater alignment with this. Animism affirms simply that a creative energy - an irresistible evanescence - permeates all existence. This Tao has no interest in discerning animate or inanimate, natural or supernatural, living or dead. It is an immanent force conferring the possibility for a mysterious kinship and participation in phenomena, beyond the division of animate and inanimate. ${ }^{88}$ The animist logics, flows, assemblages and subjective and trans-personal intensities affirmed in Deleuze and Guattari's writings, as well as in my brief ethnographic gesture here coalesce with a strong series of authors and concepts in environmental anthropology and philosophy to mobilise a cogent 'counter-logic': a radically other conceptual series of expressions regarding nature/culture relationships to those assumed in the capitalist ecologies of 'carbon earth' and 'ecosytem service commodities' described above. ${ }^{89}$

Merleau-Ponty's phenomenological writings are key in this, influencing a growing number of authors to affirm the active participation of sensual perception in a collaborative bringing forth of a world of inter-subjective comprehensibility. Thus, ' ... I do not merely encounter the tree, am not simply
83. Deleuze and Guattari, op. cit., p258.

84. Guattari, op. cit., p30.

85. Ibid., pp19-20.

86. Deleuze and Guattari, op. cit., p256.

87. Carolyn Merchant, The Death of Nature: Women, Ecology and the Scientific Revolution, San Francisco, HarperSanFrancisco, 1990 (1980); Theodore Roszak, The Vice of the Earth: An Exploration of Ecopsychology, Phanes Press, Grand Rapids, Michigan, 2002.

88. Lucien LévyBruhl, How Natives Think, Princeton, Princeton University Press, 1992 (1910); Lewis-Williams and Pearce, op. cit., p233; Low, op. cit., p50; Graham Harvey, Animism: Respecting the Living World, London, C. Hurst \& Co Publishers Ltd, 2005.

89. cf. Sian Sullivan, 'An other world is possible? On representation, rationalism and romanticism in Social Forums', Special Issue ephemera: theory and practice in organization 5(2) (2005): 370-392, online at: http://www. ephemeraweb. org/journal/5-2/52ssullivan.pdf . 
90. Maurice

Merleau-Ponty, The Phenomenology of Perception, London, Routledge, p370, (emphasis added).

91. David Abram, The Spell of the Sensuous: Perception and Language in a More-Than-Human World, London, Vintage Books, 1997.

92. Tim Ingold, The Perception of the Environment: Essays in Livelihood, Dwelling and Skill, London, Routledge, 2000, p265, after Merleau-Ponty, op. cit., and Gregory Bateson, Steps to an Ecology of Mind, Chicago, University of Chicago Press, 2000 (1972).

93. Ibid., p243.

94. Michael S. Carolan, "'I do therefore there is": enlivening socio-environmental theory',

Environmental Politics, 18(1) (2009): 1-17.

95. Ingold, op. cit., p263, after MerleauPonty.

96. Val Plumwood, 'The concept of a cultural landscape: nature, culture and agency in the land, Ethics and the Environmment, 11(2) (2006): 115-150.

97. See for example Esther Cohen Law, folklore and animal lore, Past and Present, 110 (1986): 6-37.

98. Ingold, op. cit.

99. Warwick Fox, confronted with it, but discover in this existent before me a certain nature, the notion of which I actively evolve'. ${ }^{90}$ The perceiver ('I') is understood as opening to the world through embodied senses,${ }^{91}$ mingling and resonating with other presences, and thereby in each moment bringing forth the manifest reality of that moment. This is a radical conceptual shift from the mode of speculation associated with the modern Cartesian cogito, towards the possibility of an embodied-conscious participation in existence. ${ }^{92}$ The human subject ceases to be 'a seat of awareness, bounded by the skin, and set over against the world', with the subject's 'environment' conceived as backdrop or background to human and social activity, becoming instead 'an [embodied] inhabitant of the world rather than of a space inside my head' ${ }^{93}$ Perception becomes inseparable from kinaesthetic corporeality, and the doing of perceiving manifests phenomena in processes of mutual constitution. So, as Michael S. Carolan writes, 'I do therefore there is' ${ }^{94}$ and sensing becomes a ' ... dialogic, exploratory encounter between the perceiver and the world, in which every movement on the part of the perceiver is a questioning, and every reaction on the part of the perceived is a response' ${ }^{95}$ A sense that everything has the power to do things - to assert some form of entwined agency ${ }^{96}$ - affirms and reclaims a knowledge that community, communication and commonwealth between human and non-human worlds not only are possible, but are normal. ${ }^{97}$ All these conceptions become entrances into an ethical mode of mutual constitution ${ }^{98}$ that resonates with what philosopher Warwick Fox has termed 'responsive cohesion': an ethical theory emphasising the quality of coherence residing in always-evolving relationships between phenomena, such that those that cohere - that improvise and 'groove' with each other - are those that ethically are good, and therefore sustainable, for the combined terrains of human, non-human and human-constructed worlds. ${ }^{99}$

These gestures bear little relation to the primacy of universalising and separating categories such as biological species or ecosystems services; or to genealogical rights-based discourses via which rules for correct behaviour are constructed from degrees of relatedness to a core idealised 'person'; or to the distant, flattened, dematerialised, and infinitely measurable and exchangeable earth proposed by market environmentalism. In tandem, then, these concepts become a completely other mode of cognition and experience. As such they constitute a cogent 'counter-power' that affirms immanent and emplaced ecologies of responsive intersubjective intensities as a greatly needed corrective to the escaping imperialism of environmental governance through new transcendent environmental commodity markets.

\section{ECOLOGY, CRISIS, EMPIRE AND ... MAKING SOMETHING DIFFERENT}

You have to understand the scale of this. There is $\mathrm{a}[\mathrm{n}]$... epidemic coming. It will affect the entire world. Or put into the language that stock exchanges all over the world understand, if the ... market performs as forecast billions and billions of dollars are waiting to be earned. ${ }^{100}$ 
By 2030, Carbon will be the largest commodity market in the world: \$1.62.4 trillion, about the same as the current oil market. ${ }^{101}$

This essay is an attempt to articulate and understand some of the new imperial processes of 'coding' that are making ecological phenomena legible to the logic of capital, ${ }^{102}$ whilst highlighting the strangeness of these processes in relation to othered commonplace ecologies. It is written in the shadow of the fifteenth Conference of Parties (COP15) to the United Nations Framework Convention of Climate Change in Copenhagen, where climate justice activists contesting capitalist market 'solutions' to carbon emissions are being imprisoned without public hearings, where indigenous concerns remain sidelined, and where market proposals for solving ecological crisis predominate. Through focusing on the exponentially expanding frontier of ecosystem service commodities, I hope to have illustrated some new ways in which material nature in all its organisational forms - from molecules to genes to species to ecosystems - is being nomadically liberated (or deterritorialised to use Deleuze and Guattari's term) into new abstract commodity fictions from which new financial value can be released, traded and speculated on. I have argued that new markets for ecosystem service commodities propose convenient chains of equivalence between locations, 'things' and values that are substantively incommensurable. At the same time, these discursively delegitimise and/or silence alternative perceptions that speak of the highly contingent and exclusionary nature of these new alignments.

As with the conceptual and political alchemy that transforms land into property, these deterritorialising phenomena also permit new captures and territorialisations. This is because, for these ideational values to be realised, the material natures to which they relate need to be enclosed and owned: to become property. So whilst this indeed might be a new and globally nomadic wave of primitive accumulation, it is still primitive accumulation, providing further routes via which nature and people are compelled to service capital and the ethnic-rich. ${ }^{103}$

The idiotic fallacy at the heart of these proposals is that markets do not in and of themselves embody or produce moral behaviour. Markets do not care if rainforests fall, if glaciers shrink, or if the values of indigenous cultures are displaced or captured in the service of capitalism; and it seems to be mad to think that it is only their correct construction, for instance through pricing mechanisms, that will prevent the manifestation of these losses. When nature health becomes converted into a dollar sign, it is the dollar not the nature that is valued. ${ }^{104}$ Declining commodities may assume high market values, but zero-availability, for example through extinction, equates with no value at all, becoming simply an opportunity for innovation to supply alternatives (if required). And since the 'free-market' is an emergent property of the dance of multiple commodity values, exchanges and other influencing factors, there is nothing intrinsic to this system to uphold the values of environmental health relative to the unpredictably shifting values of other commodities.
A Theory of General Ethics, Cambridge, Massachusetts, MIT Press, 2006; also see, Hugh McCullough, 'An examination of Warwick Fox's notion of responsive cohesion and its relevance for environmental theory', Paper presented at Western Political Science Associations (WPSA) annual meeting Ideas, Interests and Institutions, Vancouver, $B C$, Canada, March 19, 2009, online at: http://www. allacademic. $\mathrm{com} / \mathrm{meta} / \mathrm{p}$ mla apa_research citation/3/1/7/4/9/ p317491_index. html, accessed 23 December 2009.

100. From The Constant Gardener, Focus Features, 2005 , based on John le Carré, The Constant Gardener, London, Hodder \& Stoughton, 2001, pp315-318.

101. Advanced Conservation Strategies, 'Environmental markets', online. htt9p://www. advanced conservation. org/blog/?page id $=58$ [accessed 7 December 2009].

102. cf. Robertson, op. cit. p369.

103. Discussed further in Sian Sullivan, 'Capital's new natures: on contemporary primitive accumulation and the environmentality of 'Earth Incorporated', forthcoming. 
104. Graeme

Caughley, 'Elephants and economics',

Conservation

Biology, 7(4) (1993):

943-45.

105. Deleuze and Guattari, op. cit. p387.

106. Deleuze and Guattari, op. cit. p309.

107. Deleuze and Guattari, op. cit. p249.
It could be said that nomadic and rhizomatous organisational forms - those celebrated as 'anti-Oedipal' by Deleuze and Guattari, and inspirational for much organisation and rhetoric in critical political and activist contexts actually are hegemonic in the world of digital commodity markets and alliances with major environmental and philanthropic organisations and foundations. This reminds us, as Deleuze and Guattari do, that the "... smooth space and the [nomadic] form of exteriority do not have an irresistible revolutionary calling'. ${ }^{105}$ Deleuze and Guattari nevertheless offer a multiplicity of vibrant concepts for a theoretical disentangling of the consolidations of power in new environmental governance, as well as for opening up the different cognitive and experiential expressions of human/non-human relationships that I have described and embraced here as animist.

This essay thus is intended as a small gesture towards affirming a critical political activation of the power-full 'anti-power' of animist epistemologies and ontologies. It is a reminder of the validity of producing what Deleuze and Guattari speak of as 'the opposite of having an advantage': a call for embodying the 'becomings-woman, -child, -animal, or -molecular', through which 'nature opposes its power, and the power of music, to the machines of human beings, the roar of factories and bombers'. ${ }^{106}$ In understanding and enacting human relationships with non-human worlds, then, there is a relevant political and ethical challenge to reinsert and reactivate such different and resistant realities and practices. But this requires the discipline of not feeling alien to the world, which perhaps is the hardest step to take, when all around the world somehow is made alien to us. Nevertheless, "[f]rom the howling of animals to the wailing of elements and particles' ${ }^{107}$ we need now the courage to express a different sort of planetary sorcery.

First presented at the conference Deleuze and Activism, The Centre for Critical and Cultural Theory, Cardiff University, 12-13 November 2009. I thank Mike Hannis for lively discussion and for suggesting several references drawn on in this essay. 